\title{
Türkiye Ekonomisinde Yakınsama Hipotezi Geçerliliğinin Test Edilmesi: G7 Grubu Ülke Örneği
}

DOI: 10.26466/opus.908963

\author{
Esra Demirel* - Ünzüle Kurt ${ }^{* *}$ \\ * Araş. Gör. Dr., Çanakkale Onsekiz Mart Üniversitesi, Çanakkale/Türkiye \\ E-Posta: esrademirel@comu.edu.tr \\ ORCID: 0000-0002-5264-978X \\ ** Doç.Dr Çanakkale Onsekiz Mart Üniversitesi, Çanakkale/Türkiye \\ E- Posta: unzulekurt@comu.edu.tr \\ ORCID: $\underline{0000-0003-3406-1269}$
}

Öz

\begin{abstract}
Ülkelerin ekonomik anlamda temel amacı ekonomik büyümeyi sağlamaktır. Bu çerçevede ülkeler ekonomik büyüme ve kalkmmalarn çerçevesinde kategorize edilmiş ve azgelişmiş ve gelişmekte olan ülkeler sürekli olarak gelişmiş ülke kategorisine ulaşma eğiliminde olmuşlardır. Temelleri neo Klasik büyüme modeline dayanan yaknsama hipotezi de bu eğilimi açıllama noktasında geliştirilmiştir. Yakınsama hipotezi; Düşük gelirli ülkelerin nispeten yüksek gelirli ülkelere göre daha yüksek hızda büuyüdü̆g̈̈ ve zaman içerisinde iki tarafin gelirlerinin birbirine yaklaşttğı öngörüsü üzerine tanımlanan bir kavramdır. Hipotez sözü edilen yakmsama olgusunun gerçekleşmesi durumunda gelişmekte olan ülkelerin gelişmiş ülke kategorisine erişeceklerini ileri sürmektedir. Bu noktada çalışmada gelişmekte olan bir ülke olarak Türkiye için ekonomik büyüme sürecinde yakmsama kavramı önemli bulunmuş ve yakınsama hipotezinin Türkiye Ekonomisi için ampirik olarak test edilmesi amaçlanmaktadır. Türkiye GSMH'nın G7 ülke grubu GSMH'na yakınsamasinm araştırldığı çalışmada Dickey ve Fuller (1979) tarafindan ortaya koyulan Dickey Fuller birim kök testinin genişletilmiş hali ADF, Lee ve Strazicizh $(2003,2004)$ tarafindan geliştirilen bir kurnlmal ve iki kurnlmal LM birim kök testi kullanılmaktadır. Bu testlerin yanında ayrıca Meng ve diğerleri (2014) tarafindan önerilen kalintılarla genişletilmiş birim kök testi RALS-LM kullamlmıştır. Çalş̧ma sonucunda ilgili dönem için Türkiye ile G7 grubu arasında bir yakınsama ilişkisinin olmadığı tespit edilmiştir.
\end{abstract}

Anahtar Kelimeler: Yakınsama Hipotezi, Birim Kök Testi, RALS-LM. 


\title{
Test of the Validity of Convergence Hypothesis in Turkey's Economy: G7 Group Country Case
}

\begin{abstract}
The main purpose of the countries in economic terms is to provide economic growth. In this framework, countries were categorized within the framework of their economic growth and development, and underdeveloped and developing countries have always tended to reach the category of developed countries. The convergence hypothesis, which is based on the neoclassical growth model, has also been developed to explain this trend.Convergence hypothesis is a concept defined on foresight that lowincome countries grow at a high rate than relatively highincome countries and over time the revenues of the two sides converge. The hypothesis suggests that if the mentioned convergence phenomenon occurs, the developing countries reach the developed country category. At this point, in this study, the concept of convergence in the proses of economic growth for Turkey as a developing country is found significant and convergence hypothesis are intended to be tested empirically for Turkey economy. In the study investigating the convergence of Turkey's GDP to G7 country group's GDP is used extended version of Dickey Fuller unit root test ADF introduced by Dickey and Fuller (1979), one break and two break LM unit root test developed by Strazicizh $(2003,2004)$. In addition to these tests, the extended unit root test RALS-LM with residue recommended by Meng et.al. (2014) was used.Result of the study for the period, it was determined not to be the relationship of convergence between the G7 group and Turkey.
\end{abstract}

Key Words: Convergence Hypothesis, Unit Root Test, RALS-LM. 


\section{Giriş}

Ekonomik büyüme tarih boyunca ülkelerin nihai amacı olmuştur. Dolayısıyla ülkeler arası gelir farklılıklarının giderilmesi ülkelerin en önemli sorunları haline gelmiştir. Temelleri Neo Klasik İktisat modeline dayanan yakınsama hipotezi benzer tercihlere ve üretim olanaklarına sahip ülkelerin gelirlerinin zaman içerisinde birbirine yaklaşacağ 1 üzerinde durulmaktadır. Solow (1956) büyüme modelinin öngörülerinden biri olarak yakınsama nispeten yoksul ülkelerin zengin ülkelere göre daha hızlı büyüyerek zaman içerisinde birbirlerine yaklaşacağı yönündedir.

Yakınsama hipotezi genel çerçevede; zaman içerisinde ekonomiler arasında gelir eşitsizliklerinin kapanıp kapanmayacağı, düşük gelirli ülkelerin yüksek gelirli ülkelere göre daha hızlı büyümesi sonucu bu ülkelerin zamanla gelişmiş ülkelerin gelir seviyesine erişip erişemeyeceği, yüksek gelirli ekonomilerde ekonomik büyüme hızı zamanla yavaşlayıp yavaşlamayacağı ve en nihayetinde ekonomik büyüme noktasında uluslararası dışsallık söz konusu olup olmadığı araştırılmaktadır.

Yakınsama hipotezini ortaya atan kişi olarak Abramovitz (1986) yakınsamayı belli koşullar altında başlangıçta geride kalmanın liderden daha hızlı büyüme kabiliyeti geliştirmeyi ve üretkenliği yaratan bir süreç olarak tanımlamıştır. Yakınsama hipotezinin bahsi geçen süreci tamamlaması için gerekli üç koşul sıralanmaktadır. Bunlar; teknolojik yayılım, neo klasik büyüme modeli ve küreselleşmedir (Rassekh 1998).

Solow modelinde ekonomik büyümenin başlıca dinamiği olarak tanımlanan teknolojik gelişme ülkeler arasındaki gelir yakınsaması açısından da önemli bir role sahiptir. Başlangıçta GSMH'sı düşük ülkeler daha yüksek bir büyüme oranına sahip olacaktır. Bu durum modeled sermayenin azalan verimlilik durumunda çalıştığı varsayımına dayanmaktadır. Bu durumda başlangiçta düşük sermaye/emek oranına sahip ülkelerin doğal bir sonuç olarak yüksek olan marjinal sermaye verimliliği diğer faktörler eşit kabul edildiğinde bu ekonomilerin gelişmiş ekonomilere göre nispeten daha hızlı büyümesini sağlayacaktır. Solow modeli, ulkeler arası gelir farklılıklarını, yatırım oranlarındaki, nuifus artıs, hızındaki ve teknolojideki dıs,sal farklılıklarla açılamaktadır. Burada yakınsamaya yol açan en önemli faktör ölçeğe göre getiri 
farklılıklarıdır. Gelişmiş ülkelerdeki ölçeğe göre azalan getiri zaman içerisinde tam tersi olan gelişmekte ülkelerde ekonomik büyüme rakamlarının bu ülkelere yaklaşması ile sonuçlanmaktadır.

Yakınsamanın kaynakları bağlamında değerlendirildiğinde teknolojik yayılım önemli bir faktör olarak ampirik çalışmalara konu olmuştur. Bu çalışmaların başında Abromovatiz (1986), Dowrick ve Nguyen (1989) ve Bernard ve Jones (1996) başta gelen çalışmalardır. Abromovatiz (1986) çalışmasında yakınsama hipotezinin gerçekleşme koşulunu sosyal kabiliyet olarak tanımlamaktadır. Ekonomik büyüme sürecinde teknolojik gerilik durumunun bir avantaja dönüşerek yakınsama mekanizmasının harekete geçmesi kültürel gelişim, girişimcilik faaliyetlerinin desteklenmesi, teknik ilerleme sürecini destekleyen kurumsal bir yapının kurulması olarak tanımlanan sosyal kabiliyet kavramının oluşturulması ile mümkün olmaktadır. Bernad ve Jones (1996) çalışmasında nispeten düşük gelirli ülkelerin yüksek gelirli ülkelerin teknolojilerine adapte olabileceği üzerinde durmakta ve taklitçi bir teknolojinin maliyetinin daha düşük olduğunu ve dolayısıyla bu durumun büyüme hızını arttırdığını ileri sürmektedir.

Ampirik literatürde yakınsama incelemeleri beta yakınsaması ve sigma yakınsaması olmak üzere iki türde yapılmaktadır. $\beta$-yakınsaması fakir ülkelerin zengin ülkelere gore büyüme hızlarının daha yüksek olması olarak ifade edilmektedir (Sala-i-Martin, 1995, s.3). Beta yakınsaması, ekonominin başlangıç seviyesindeki kişi başına gelirle sonraki dönemlerindeki kişi başına gelir düzeylerinin büyüme oranları arasında negatif bir ilişki olduğunu ifade eder. Sigma yakınsaması ise kişi başına gelirin standart sapmasının zamanla sürekli bir şekilde azaldığını öne sürmektedir. Beta yakınsaması ülkeler arası gelir yakınsamasını ortaya koyarken sigma yakınsaması bölge ya da bir ülke grubu yakınsamasını açıklamaktadır.

Yakınsama kavramı açıklandığı üzere iktisat literatüründe üzerinde oldukça çalışılmış önemli bir konudur. Zira dünya üzerinde gelir dağılımı adaletinin sağlanması, ülkelerin gelirlerinin birbirlerine yaklaşması hem ekonomik hem sosyal anlamda son derecede önemlidir. Bu bağlamda iktisat disiplini gelir yakınsaması konusuna gereken önemi atfetmiş ve kaynaklarını araştırma yönünde çalışmalar sürdürülmektedir. Bu çalışmada konunun önemi dolayısıyla gelişmekte olan bir ülke 
olarak Türkiye Ekonomisi GSMH'sının gelişmiş bir ülke grubu olan G7 grubuna yakınsamasının araştırılması ve yakınsama noktasında politika önerisi geliştirilebilmesi amacı ile hazırlanmıştır.

Yakınsama hipotezi ile ilgili ilgili literatür oldukça geniştir. Literatür incelendiğinde yakınsama hipotezinin ülkeler ve bölgeler arasından olmak üzere iki farklı biçimde yapıldığı görülmektedir. Hem uluslararası hem de Türkiye özelinde yakınsama hipotezini konu alan çalışmalar tablo 1'de özetlenmiştir.

Tablo 1. Yakınsama Hipotezi Literatür Özeti

\begin{tabular}{|c|c|c|}
\hline Yazar & Dönem/Kapsam & $\begin{array}{l}\text { Yakınsama } \\
\text { Var/Yok }\end{array}$ \\
\hline Baumol (1986) & 1870-1979/16 OECD ülkesi & Var \\
\hline Barro (1991) & 1960-1985/98 Ülke & Var \\
\hline Barro ve Salai Martin (1992) & 48 ABD Eyaleti & Var \\
\hline Mankiv vd. (1992) & 1960-85/98 Ülke & Var \\
\hline Sala-i Martin (1995) & 1960-90/110 Ülke & Yok \\
\hline İslam (1995) & 1960-85/96 Ülke & Var \\
\hline Filiztekin (1998) & 1975-1995/ Türkiye /67 il 7 sektör & Var \\
\hline Filiztekin (1999) & 1975-95/Türkiye/ 7 Bölge & Var \\
\hline Tansel ve Güngör (1999) & 1975-95/Türkiye/İller & Var \\
\hline Berber vd. (2000) & 1975-97/ Türkiye/7Bölge & Yok \\
\hline Yamak ve Artan (2000) & 1975-97/Türkiye/ 7 Bölge & Yok \\
\hline Erk vd. (2000) & 1979-97/Türkiye/67 il & Yok \\
\hline Kim (2001) & 1960-92/17 Asya Ülkesi & Var \\
\hline Sağbaş (2002) & 1986-97/Türkiye/67 İl & Var \\
\hline Altınbaş vd. (2002) & 1987-98/Türkiye/81 İl & Yok \\
\hline Doğruel ve Doğruel (2003) & 1987-99/Türkiye/Illler & Yok \\
\hline Beyaert (2003) & 1970-2000/AB-15 & Var \\
\hline Gezici ve Hewings (2004) & 1980-1997/İBB II-İller & Yok \\
\hline Karaca (2004) & 1975-2000/Türkiye/67 İl & Yok \\
\hline Yıldırım (2005) & 1990-2001/Türkiye/İller & Var \\
\hline Dufrenot ve Sanon (2005) & 1985-2003/ECOWAS & Yok \\
\hline Temel ve Tansel (2005) & 1975-90/Türkiye/Illler & Var \\
\hline Ersungur ve Polat (2006) & 1987-2000/IBBB I & Zayif Var \\
\hline Aldan (2006) & 1987-2001/Türkiye/İller & Yok \\
\hline Yıldırım ve Öcal (2006) & 1979-2001/Türkiye/İller & Var \\
\hline Kılıçaslan ve Özatağan (2007) & 1987-2000/Türkiye/İller & Var \\
\hline Halaç ve Kuştepeli (2008) & 1999-2001/Türkiye/7 Bölge & Yok \\
\hline Yamanoğlu (2009) & 1990-2008/Türkiye/IBB II & Var \\
\hline Önder vd. (2010) & 1980-2001/Türkiye İBB II & Var \\
\hline Zeren ve Yllancı (2011) & 1990-2001/Türkiye/İBB II & Var \\
\hline Beypınar ve Erkut (2011) & 1990-2000/Türkiye/İller & Var \\
\hline Erlat (2012) & 1975-2001/Türkiye/7 Bölge ve İller & Var \\
\hline Kırdar ve Saraçoğlu (2012) & 1975-2000/Türkiye/Iller & Yok \\
\hline Abdioğlu ve Uysal (2013) & 2004-2008/Türkiye/İBB II & Yok \\
\hline Gögül ve Korap (2014) & 1970-2012/ 26 OECD Ülkesi & Var \\
\hline Gerni ve Sarı (2015) & 2004-2012/İBB II/İller & Var \\
\hline Akıncı (2017) & 1980-2014/Türkiye/IBB I & Yok \\
\hline Soyyiğit ve Nas (2018) & 2004-2014/Türkiye/IBB I/İler & Var \\
\hline Yoloğlu (2021) & 1985-2004/Türkiye/İlçe & Yok \\
\hline
\end{tabular}


Gerek ülke bazına gerek bölge bazında incelendiğinde; yakınsama sürecini temsil eden değişken olarak Filiztekin (1999), Berber vd. (2000), Erk vd. (2000), Altınbaş vd. (2002), Sağbaş (2002), Doğruel ve Doğruel (2003), Gezici ve Hawings (2004), Karaca (2004), Aldan (2006), Ersungur ve Polat (2006), Yıldırım ve Öcal (2006), Kılıçaslan ve Özată̆an (2007), Yamanoğlu (2008), Halaç ve Kuştepeli (2008), Zeren ve Yılancı (2011), Kırdar ve Saraçoğlu (2012), Elat (2012), Soyyiğit ve Nas (2018) "kişibaşı gelir" değişkeninin seçildiği görülmektedir. Bunun yanı sıra Tansel ve Güngör (1999), Temel ve Tansel (2005), Baypınar ve Erkut (2011) "emek verimliliği" değişkeni de yine yakınsama sürecini temsilen kullanılan bir diğer değişkendir. Literatür bağlamında çalışmalarda genel olarak panel veri yöntemleri, yatay kesit testleri ve birim kök testleri kullanılmıştır. Literatür taraması sonuçları Türkiye ekonomisi için yakınsama süreçlerinin incelenen dönem farklılıklarına bağlı olarak değiştiği gözlemlenmektedir.

Yakınsama hipotezinin temeli yoksul ülkelerin zengin ülkelerle kıyaslandığında daha hızlı büyüdüğü, yani belirli bir dönemin başındaki gelir ile gelirin artma hızı arasında tesr orantı olduğu kabulüne dayanmaktadır. Az gelişmiş ya da gelişmekte olan ülkelerin büyüme oranlarının gelişmiş ülkelerle karşılaştırıldığında daha fazla olacağı varsayılmaktadır. Bu bağlamda gelişmiş ve gelişmekte olan ülkeler arasındaki büyüme farkının zamanla kapanacağı kabul edilmektedir (Yılmaz ve Kesbiç, 2020: 1276).

Yakınsama hipotezinin varsayımı dikkate alındığında gelişmekte olan ülkeler arasında bulunan Türkiye'nin GSYH'sının G7 ülke grubunun GSYH'sına yakınsaması beklenmektedir. Bu bağlamda yapılan çalışmada Türkiye'de GSYH'nın 1970-2019 yılları arasında G7 ülke grubunun GSYH'sına yakınsayıp yakınsamadığının bulunması amaçlanmaktadır.

\section{Yöntem}

Bu çalışmada GSYH yakınsamasını incelemek için Dickey ve Fuller (1979) tarafından ortaya koyulan Dickey Fuller birim kök testinin genişletilmiş hali ADF, Lee ve Strazicizh (2003, 2004) tarafından geliştirilen bir kırılmalı ve iki kırılmalı LM birim kök testi kullanılmaktadır. Bu testlerin yanında ayrıca Meng ve diğerleri (2014) tarafından 
önerilen kalıntılarla genişletilmiş birim kök testi RALS-LM kullanılmaktadır.

Dickey-Fuller'in bağımlı değişkenin gecikmeli değerlerini bağımlı değişken olarak modele eklediği ADF birim kök testinin üç temel modeli vardır (Sevüktekin ve Çınar, 2017, s.335-336):

$$
\Delta Y_{t}=\delta Y_{t-1}+\sum_{i=1}^{k} \delta_{i} \Delta Y_{t-1}+\varepsilon_{t} \quad \text { Sabitsiz ve Trendsiz Model }
$$

$$
\Delta Y_{t}=\mu+\delta Y_{t-1}+\sum_{i=1}^{k} \delta_{i} \Delta Y_{t-1}+\varepsilon_{t} \quad \text { Sabitli ve Trendsiz Model }
$$

$\Delta Y_{t}=\mu+\beta T+\delta Y_{t-1}+\sum_{i=1}^{k} \delta_{i} \Delta Y_{t-1}+\varepsilon_{t} \quad$ Sabitli ve Trendli Model (3)

Yukarıdaki her üç model için de temel hipotez birim kökün varlığıdır. Alternatif hipotez ise birim kök yoktur, yani seri durağandır.

Yapısal kırılmalı birim kök testleri yapısal kırılmaya izin vermeyen ADF gibi birim kök testlerine göre daha üstün oldukları için bu çalışmada yapısal kırılmayı da dikkate alana LM birim kök testi kullanılmaktadir.

LM testinde $\mathrm{A}, \mathrm{B}$ ve $\mathrm{C}$ olmak üzere üç model bulunmaktadır. A modeli sabitte kırılmayı, B modeli trendde kırılmayı, C modeli ise hem sabitte hem trendde kırılmayı dikkate almaktadır. Bu üç model içinde hem sabitte hem trendde kırılmaya izin veren $C$ modeli diğer iki modelle kıyaslandığında daha üstündür (Sen, 2003, s.184). Bu sebeple bu çalışmada C modeli kullanılmaktadır.

LM birim kök testi regresyonu aşağıdaki gibidir:

$$
y_{t}=\delta Z_{t}+e_{t} \quad e_{t}=\beta e_{t-1}+\varepsilon_{t}
$$

Bu denklemde $Z_{t}$ dişsal değişken vektörünü, $\varepsilon_{t}$ iid $N\left(0, \sigma^{2}\right)$ özelliğini gösteren kalıntıları belirtmektedir. LM birim kök test istatistiği aşağıdaki regresyondan bulunmaktadır:

$$
\Delta y_{t}=\delta^{\prime} \Delta Z_{t}+\varphi \bar{S}_{t-1}+u_{t}
$$

Tek kırılmalı $C$ modelinde $t \geq T_{B}+1$ için $D T_{t}=t-T_{B}$, diğer durumlar için $D T_{t}=0^{\prime}$ dır. Bir kırılmalı LM testi için hipotezler aşağıdaki gibidir:

$$
\begin{aligned}
& H_{0}: y_{t}=\mu_{0}+d_{1} B_{1}+d_{2} B_{2}+y_{t-1}+v_{1 t} \\
& H_{1}: y_{t}=\mu_{1}+\gamma t+d_{1} D_{1}+d_{2} D_{2}+v_{2 t}
\end{aligned}
$$


İki kırılmalı $\mathrm{C}$ modelinde $t \geq T_{B j}$ için $D T_{j t}=t-T_{B j}$, diğer durumlarda $D T_{j t}=0$ ifade etmektedir. İki kırılmalı LM testi için hipotezler aşağıdaki gibidir:

$$
\begin{aligned}
& H_{0}: Y_{i, t}=\mu_{0}+d_{1} B_{1 t}+d_{2} B_{2 t}+d_{3} D_{1 t}+d_{4} D_{2 t}+Y_{i, t-1}+v_{1 t} \\
& H_{1}: Y_{i, t}=\mu_{1}+\gamma t+d_{1} D_{1 t}+d_{2} D_{2 t}+D T_{1 t}+D T_{2 t}+v_{2 t}
\end{aligned}
$$

Sıfır hipotezi birim kökün varlığını ifade ederken alternatif hipotez birim kökün olmadığını; yani serinin durağan olduğunu belirtmektedir.

Bu çalışmada kullanılan bir diğer test RALS-LM Meng ve diğerleri (2014) tarafından literatüre dahil edilmiştir. Regresyon denklemindeki hatalarda normallikten sapma meydana geldiğinde var olan bilgileri kullanan yapı RALS prosedürü olarak adlandırılmaktadır (Konat, 2020, s.66).

$$
\Delta y_{t}=\delta^{\prime} \Delta z_{t}+\varphi \tilde{y}_{t-1}+e_{t}
$$

Burada $\tilde{y}_{t}=y_{t}-\widetilde{\Psi}-z_{t} \tilde{\delta}$ dır. Regresyon modeli aşağıdaki gibidir:

$$
\Delta y_{t}=\delta^{\prime} \Delta z_{t}+\varphi \tilde{y}_{t-1}+\sum_{j=1}^{p} c_{j} \Delta \tilde{y}_{t-j}+e_{t}
$$

RALS-LM testleri için de temel hipotez birim kökün varlığını belirtirken alternatif hipotez birim kökün bulunmadığını ifade etmektedir.

\section{Bulgular}

Çalışmada kullanılan G7 ülke grubunun ve Türkiye'nin 1970-2019 tarihleri arasında gayrisafi yurtiçi hasıla yıllık verisi Ekonomik Kalkınma ve İşbirliği Örgütü (OECD) veri tabanından elde edilmiştir. Gayrisafi yurtiçi hasıla verisi milyon dolar birimi ile ifade edilmektedir. Tablo 2' de G7 ülkelerinin ve Türkiye'nin gayrisafi yurtiçi hasıla verisine ait tanımlayıcı istatistikleri verilmektedir.

Tablo 2. 1970-2019 Dönemi G7 Ülkeleri ve Türkiye'nin GSYH Tanımlayıcı İstatistikleri

\begin{tabular}{lllllll}
\hline Ülkeler & Ortalama & Min. & Maks. & $\begin{array}{l}\text { Standart } \\
\text { Sapma }\end{array}$ & Çarpıklık & Basıklık \\
\hline Türkiye & 735231 & 62507 & 2300826 & 657385 & 1.1574 & 3.2199 \\
\hline G7 & 2635864 & 345032 & 6081225 & 1713335 & 0.3692 & 1.9228 \\
\hline
\end{tabular}


Meng ve diğerleri (2013) yaptıkları çalışmada yakınsama hipotezini sınamak için aşağıdaki deklemi kullanmaktadır:

$$
T U R=\ln \left(\frac{E_{T u ̈ r k i y e}}{\bar{E}_{G 7}}\right)
$$

Denklem (6)'ya göre dönüştürülen serilerin durağanlığı Dickey ve Fuller (1979) tarafından ortaya koyulan Dickey Fuller birim kök testinin genişletilmiş hali ADF, Meng ve diğerleri (2014) tarafından geliştirilen RALS-LM birim kök testi, Lee ve Strazicizh (2003, 2004) tarafindan geliştirilen bir kırılmalı ve iki kırılmalı LM birim kök testi ile araştırılmaktadır. Yapılan testlerin sonucunda seri birim köklü bulunursa yakınsama olmadığı, durağan tespit edilirse yakınsama olduğu söylenmektedir.

1970-2019 dönemi için hesaplanan yakınsama serisine LM, RALS-LM ve ADF birim kök testlerinin uygulanmasıyla elde edilen sonuçlar tablo 3'te gösterilmektedir. Bu testlerin sonuçlarına göre TUR serisinin birim köklü olduğunu ifade eden temel hipotez reddedilememiştir. Bu bağlamda TUR serisi bu üç teste göre de birim köklü bulunmuştur.

Tablo 3. ADF, LM ve RALS-LM Birim Kök Testi Sonuçlan

\begin{tabular}{|c|c|c|c|c|c|}
\hline \multicolumn{6}{|l|}{ LM } \\
\hline & & \multirow[b]{2}{*}{$\tau_{L M}$} & \multicolumn{3}{|c|}{ Kritik Değerler } \\
\hline & & & $\% 1$ & $\% 5$ & $\% 10$ \\
\hline TUR & -1.1767 & & -3.597 & -3.031 & -2.745 \\
\hline \multicolumn{6}{|c|}{ RALS-LM } \\
\hline & & & \multicolumn{3}{|c|}{ Kritik Değerler } \\
\hline & $\rho^{2}$ & $\tau_{R A L S-L M}$ & $\% 1$ & $\% 5$ & $\% 10$ \\
\hline TUR & 0.82966 & -1.3468 & -3.089 & -2.426 & -2.081 \\
\hline \multicolumn{6}{|l|}{ ADF } \\
\hline & & & \multicolumn{3}{|c|}{ Kritik Değerler } \\
\hline & & $\tau_{A D F}$ & $\% 1$ & $\% 5$ & $\% 10$ \\
\hline TUR & -1.2346 & & -4.1567 & -3.5043 & -3.1818 \\
\hline
\end{tabular}

1970-2019 dönemi için hesaplanan TUR gayri safi yurtiçi hasıla yakınsama serisine bir yapısal kırılmalı LM ve RALS-LM birim kök testlerinin uygulanmasıyla elde edilen sonuçlar tablo $4^{\prime}$ te gösterilmektedir. $\mathrm{Bu}$ testlerin sonuçlarına göre TUR serisinin birim köklü olduğunu ifade eden temel hipotez bir kırılmalı RALS-LM testinde reddedilemezken bir kırılmalı LM testinde reddedilmektedir. Bu bağlamda TUR serisi bir kırılmalı RALS-LM testine göre birim köklü, bir kırılmalı LM testine göre ise $\% 1$ anlamlılık düzeyinde durağan bulunmuştur. 
Tablo 4. Bir Yapısal Kırılmalı LM ve RALS-LM Birim Kök Testi Sonuçları

\begin{tabular}{|c|c|c|c|c|c|c|}
\hline \multicolumn{7}{|l|}{$\underline{\mathrm{LM}}$} \\
\hline & & \multicolumn{5}{|c|}{$\underline{\text { Kritik Değerler }}$} \\
\hline & & $\tau_{L M}$ & Kırılma Tarihi & $\% 1$ & $\% 5$ & $\% 10$ \\
\hline & $-6.2562^{*}$ & & 1996:01 & -4.8939 & -4.3292 & -4.0479 \\
\hline \multicolumn{7}{|c|}{ RALS-LM } \\
\hline & & \multicolumn{5}{|c|}{ Kritik Değerler } \\
\hline & $\rho^{2}$ & $\tau_{R A L S-L M}$ & Kırılma Tarihi & $\% 1$ & $\% 5$ & $\% 10$ \\
\hline TUR & 0.65231 & -1.5265 & 1997:01 & -3.543 & -2.932 & -2.619 \\
\hline
\end{tabular}

Not: *\%1 anlamlılı düzeyinde dură̆anlı̆̆l ifade etmektedir.

1970-2019 dönemi için hesaplanan TUR serisine iki yapısal kırılmalı LM ve RALS-LM birim kök testlerinin uygulanmasıyla elde edilen sonuçlar Tablo 5'te gösterilmektedir. Bu testlerin sonuçlarına göre TUR serisinin birim köklü olduğunu ifade eden temel hipotez iki kırılmalı RALS-LM testinde reddedilemezken iki kırılmalı LM testinde reddedilmektedir. Bu bağlamda TUR serisi iki kırılmalı RALS-LM testine göre birim köklü, iki kırılmalı LM testine göre ise \%1 anlamlılık düzeyinde durağan bulunmuştur.

Tablo 5. İki Yapısal Kınlmalı LM ve RALS-LM Birim Kök Testi Sonuçları

\begin{tabular}{|c|c|c|c|c|c|c|}
\hline \multicolumn{7}{|l|}{ LM } \\
\hline & & \multirow[b]{2}{*}{$\tau_{L M}$} & \multirow[b]{2}{*}{ Kırılma Tarihi } & \multicolumn{3}{|c|}{ Kritik Değerler } \\
\hline & & & & $\% 1$ & $\% 5$ & $\% 10$ \\
\hline & $-10.7923^{*}$ & & 1996:01 & -7.004 & -6.185 & -5.828 \\
\hline TUR & & & 2015:01 & & & \\
\hline \multicolumn{7}{|c|}{ RALS-LM } \\
\hline & & & & \multicolumn{3}{|c|}{ Kritik Değerler } \\
\hline & $\rho^{2}$ & $\tau_{R A L S-L M}$ & Kırılma Tarihi & $\% 1$ & $\% 5$ & $\% 10$ \\
\hline & 0.82966 & -1.3468 & 1993:01 & -3.587 & -2.991 & -2.687 \\
\hline TUR & & & 1997:01 & & & \\
\hline
\end{tabular}

Not: *\%1 anlamlılı düzeyinde dură̆anlığ ifade etmektedir.

\section{Tartışma ve Sonuç}

Yakınsama hipotezi gelişmekte olan ülkelerin GSMH hasılalarındaki büyüme hızının gelişmiş ülkelerinkinden daha yüksek olduğu ve dolaysıyla söz konusu ülkelerin potansiyel kaynaklarını harekete geçirdiklerinde zaman içerisinde gelişmiş ülkelerin büyüme rakamlarına erişebilecekleri fikrinden hareket etmektedir. Bu bağlamda çalı̧̧mada 
Türkiye ekonomisi ele alınmış ve G7 ülke grubu ile yakınsama hipotezinin varlığı sorgulanmıştır.

Türkiye'nin başka ülkelerle olan ilişkisi ve ekonomik gerilimler gibi sebepler yakınsamamaya yol açabildiği için iki yapısal kırılmalı birim kök testlerinin sonuçları bir yapısal kırılmalı ve kırılmasıza göre daha güçlü sonuçlar vermektedir. RALS-LM testleri klasik LM testlerine göre daha güçlü sonuçlar vermektedir (Meng vd., 2014, s.352). Ayrıca Hepsağ ve Akçalı (2019) yaptıkları çalışmada RALS-LM testlerinin geleneksel birim kök testlerine göre daha güçlü testler olduğunu göstermektedir. Bu bağlamda yapılan çalışmada Türkiye'nin GSYH'sı G7 ülkelerinin GSYH'sına yakınsamadığı tespit edilmiştir. Bu sonuç bizlere Türkiye'nin GSYH büyüme hızının G7 ülkeleri karşısında beklenendan daha düşük olarak gerçekleştiğini göstermektedir.

Analiz sonuçları değerlendirildiğinde ülkenin potansiyel kaynaklarının harekete geçirilmesi sağlanarak başka bir ifade ile oldukça önemli faktör stoklarına sahip olan Türkiye ekonomisinin mevcut bu kaynakları aktif hale getirebilmesi yakınsama hipotezinin geçerliliğinin sağlanması için önemli bulunmuştur. Türkiye'de üretime daha çok önem verilerek güçlü firmaların kurulmasıyla katma değeri yüksek ürünlerin üretilmesi GSYH'nın artma hızını yükseltecektir. Üretime yönelik kurulan firmaların son teknolojiden faydalanması, kapasite oranlarının yüksek olması firmaların küresel açıdan rekabet yeteneklerini arttıracaktır. Ayrıca üretim sektörünün yaşadığı fiziki imkanların yetersizliği, vasıflı işgücü sağlanamaması, maliyetlerin yüksek olması gibi sorunların çözüme ulaşması Türkiye'de imalat sanayiinin gelişmesini sağlayacaktır. Bu bağlamda üretimin artışı sağlanarak GSYH'nın büyüme hızının arttırılması sağlanmalıdır. 
EXTENDED ABSTRACT

\title{
Test of the Validity of Convergence Hypothesis in Turkey's Economy: G7 Group Country Case
}

\author{
Esra Demirel- Ünzüle Kurt \\ Çanakkake Onsekiz Mart Univesity
}

,Economic growth has been the ultimate goal of countries throughout history. Therefore, the elimination of income differences between countries has become the most important problem of countries. The convergence hypothesis, which is based on the Neo-Classical Economics model, focuses on the fact that the incomes of countries with similar preferences and production possibilities will converge over time. Convergence predicts that relatively poor countries will grow faster than rich countries and converge over time.

Convergence hypothesis in the general framework; Whether income inequalities between economies will close over time, whether low-income countries will grow faster than high-income countries, whether these countries will reach the income level of developed countries over time, whether the economic growth rate in high-income economies will slow and finally, whether international externalities are in question at the point of economic growth is under investigation.

Abramovitz (1986), who put forward the convergence hypothesis, defined convergence as a process where under certain conditions lagging behind at the beginning creates the ability to grow faster than the leader and creates productivity. Three conditions are listed for the convergence hypothesis to complete the aforementioned process. These; technological diffusion, neoclassical growth model and globalization (Rassekh 1998).

As explained, the concept of convergence is an important issue that has been studied extensively in the economics literature. Because it is extremely important both economically and socially to ensure the justice of income distribution in the world and to bring the incomes of the countries closer to each other. In this context, the discipline of economics has attached the necessary importance to the issue of income convergence and studies are continuing to investigate its sources. In this study, due to the importance of the 
subject, it has been prepared with the aim of investigating the convergence of the GNP of the Turkish Economy as a developing country to the G7 group, which is a developed country group, and to develop a policy proposal at the point of convergence. The relevant literature on the convergence hypothesis is quite extensive. When the literature is examined, it is seen that the convergence hypothesis is made in two different ways, between countries and regions.

The basis of the convergence hypothesis is based on the assumption that poor countries grow faster compared to rich countries, that is, there is a positive correlation between the income at the beginning of a certain period and the rate of increase in income. It is assumed that the growth rates of underdeveloped or developing countries will be higher when compared to developed countries. In this context, it is accepted that the growth gap between developed and developing countries will close over time (Y1lmaz and Kesbic, 2020: 1276).

Considering the assumption of the convergence hypothesis, the GDP of Turkey, which is among the developing countries, is expected to converge to the GDP of the G7 country group. In this context, it is aimed to find out whether the GDP in Turkey converges to the GDP of the G7 country group between 1970-2019.

In this study, to examine GDP convergence, the extended version of Dickey Fuller unit root test introduced by Dickey and Fuller (1979), ADF, onebreak and two-break LM unit root test developed by Lee and Strazicizh $(2003,2004)$ are used. In addition to these tests, the extended unit root test RALS-LM with residues suggested by Meng et al. (2014) is also used. As a result of the tests, it is said that there is no convergence if the series has a unit root, and if it is found to be stationary, there is convergence.

First, the TUR convergence series was calculated to examine the convergence. LM, RALS-LM and ADF unit root tests were applied to the convergence series calculated for the period 1970-2019. According to the results of these tests, the basic hypothesis stating that the TUR series has a unit root could not be rejected. In this context, the TUR series was found to have a unit root according to these three tests.

A structural break LM and RALS-LM unit root tests were applied to the TUR convergence series calculated for the period 1970-2019. According to the results of these tests, the basic hypothesis stating that the TUR series has 
a unit root cannot be rejected in a RALS-LM test with a break, but is rejected in a LM test with a break. In this context, the TUR series was found to be stationary with a unit root according to the RALS-LM test with one break, and stationary at the $1 \%$ significance level according to the LM test with one break.

Two structural break LM and RALS-LM unit root tests were applied to the TUR series calculated for the period 1970-2019. According to the results of these tests, the basic hypothesis stating that the TUR series has a unit root cannot be rejected in the two-break RALS-LM test, but it is rejected in the two-break LM test. In this context, the TUR series was found to be stationary with unit root according to the RALS-LM test with two breaks and at a significance level of $1 \%$ according to the LM test with two breaks.

When the analysis results are evaluated, it has been found important for the validity of the convergence hypothesis that the potential resources of the country are activated, in other words, the Turkish economy, which has very important factor stocks, can activate these existing resources. Production of high value-added products with the establishment of strong companies by giving more importance to production in Turkey will increase the rate of increase in GDP. The fact that the companies established for production benefit from the latest technology and the high capacity ratios will increase the global competitiveness of the companies. In addition, the solution of problems such as the inadequacy of the physical facilities experienced by the production sector, the lack of qualified labor force, and the high costs will enable the development of the manufacturing industry in Turkey. In this context, it should be ensured that the growth rate of GDP is increased by increasing production.

\section{Kaynakça/References}

Abdioğlu, Z. ve Uysal, T. (2013). Türkiye'de bölgeler arası yakınsama: Panel birim kök analizi. Atatürk Üniversitesi İktisadi ve İdari Bilimler Dergisi, 27, 125-143.

Abramowitz M. (1986). Cathing up, forging ahead, and falling behind. Journal of Econonmic History, 46(2), 385-406 
Altınbas, S., Dogruel, F. ve Günes, M. (2002). Türkiye'de boilgesel yakınsama: Kalkınmada öncelikli iller politikası başarılı mı?. VI. ODTÜ Uluslararası Ekonomi Kongresi, 1-21.

Barro, R. J. (1991). Economic growth in a cross section countries. The Quarterly Journal of Economics, 106, 407-443.

Barro, R. J. ve Sala-i-Martin, X. (1992). Convergence. Journal of Political Economy, 100, 223-251.

Baumol, W. J. (1986). Productivity growth, convergence and welfare: What the long-run data show. The American Economic Review, 76, 1072- 1085.

Baypınar, M.B. ve Erkut, G. (2011). Ekonomik küreselleşme ve Türkiye'de bölgesel üretkenlik düzeylerinde yakınsama. İTÜ Dergisi, 10(1), 61-70.

Berber, M., Yamak, R. ve Seyfettin, A. (2000). Türkiye'de yakınlaşma hipotezinin bölgeler bazında geçerliliği üzerine ampirik bir çalışma: 1975-1997. 9. Ulusal Bölge Bilimi ve Bölge Planlama Kongresi Bildiriler Kitabı, s.51-59.

Beyaert, A. (2003). Growth Convergence in europe: A panel data approach with bootstrap. II Workshop on International Economics, s.1-21.

Dickey, D. A. ve Wayne A. F. (1979). Distribution of the estimators for autoregressive time series with a unit root. Journal of the American statistical association, 74(366), 427-431.

Doğruel, F. ve Doğruel, A.S. (2003). Türkiye'de bölgesel gelir farklılıkları ve büyüme. Köse, A.H., Şenses, F. ve Yeldan, E. (der.), İktisat Üzerine Yazılar I: Küresel Düzen, Birikim, Devlet ve Simıflar-Korkut Boratav'a Armağan içinde (s.287-318), İstanbul: İletişsim Yayınları.

Dowrick S.N., Nguyen D. (1989). OECD comperative economic growth 1980-85, Catch Up-and Convergence. The Amercan Review, 79(5), 11030.

Dufrenot, G. ve Sanon, G. (2007). Testing real convergence in the ECOWAS countries in presence of heterogeneous long-run growths : A panel data study. CREDIT Research Paper, 05(14), 1-30.

Erk, N., Ates, S. ve Direkçi, T. (2000). Convergence and Growth within GAP Region (South Eastern Anatolia Project) and Overall Turkey's Regions. IV. ODTÜ Uluslararası Ekonomi Kongresi, s.1-31.

Erlat, H. (2012). Türkiye' de bölgesel yakınsama sorununa zaman dizisi yaklaşım1. Türkiye Ekonomi Kurumu Tartışma Metni, 64, 251-276.

Ersungur, S. M. ve Polat, O: (2006). Türkiye'de bölgeler arasında yakınsama analizi. Atatürk Üniversitesi Sosyal Bilimler Enstitüsü Dergisi , 8, 336-343.

Filiztekin, A. (1998). Convergence across industries and provinces in Turkey. Koç University Working Paper, 8, 127. 
Filiztekin A. (1999). Convergence across Turkish provinces and sectoral dynamics. Backgroundpaper for the report Turkey: Economic reforms, living standards and social welfare study ,World Bank Report20029-TU, Poverty Reduction and Economic Management Unit, World Bank.

Gerni, C., Sarı, S., Sevinc, H. ve Emsen, O.S. (2015). Bölgesel dengesizliklerin giderilmesinde yatırım teşviklerinin rolü ve başarı kriteri olarak yakınsama analizleri: Türkiye örneği. 2015 International Conference On Eurasian Economies içinde (s.311-320). Istanbul: Eurasian Economists Association.

Gezici, F. ve Hewings, G.J. (2004). Regional convergence and the economic performance of peripheral areas in Turkey. Review of Urban and Regional Development Studies, 16(2), 113-132.

Halac, U. ve Kuştepeli, Y. (2008). Türkiye'de bölgesel gelirin yakınsaması: Gelir dağlımı açısından bir degerlendirme. Discussion paper Series, 08(01), 113.

Hepsağ, A. ve Yaşar Akçalı, B. (2019). Finansal zaman serilerinde birim kök hipotezinin test edilmesinde kalıntılarla genişletilmiş en küçük kareler yöntemi yaklaşımı: Rasyonel fiyat köpükleri üzerine bir uygulama. XIII. International Balkan and Near Eastern Congress Series on Economics, Business and Management (IBANESS), Tekirdağ, Turkey.

Islam, N. (1995). Growth empirics: A panel data Approach. The Quarterly Journal of Economics, 110, 1127-1170.

Karaca, O. (2004). Türkiye'de bölgeler arası gelir farklılıkları: Yakınsama var mı?. Türkiye Ekonomi Kurumu Tartısma Metni, 7, 1-16.

Kılıçaslan, Y., ve Özatağan, G. (2007) Impact of relative population change on regional income convergence: evidence from Turkey. In Review of Urban and Regional Development Studies, 19(3), 210-223.

Kırdar, M.G. ve Saracoğlu, D.S. (2012). İç göç bölgesel yakınsama sorunu ve ekonomik büyüme: Türkiye örneği, (No.2012/75) Discussion Paper. Turkish Economic Association.

Kim, J. U. (2001). Empirics for economic growth and convergence in Asian economies: A panel data approach. Journal of Economic Development, 26, 4959.

Konat, G. (2020) Kalıntılarla genişletilmiş yeni bir panel birim kök test önerisi: Ralscrps testi (Doktora Tezi). İnönü Üniversitesi, Malatya. 
Lee, J. ve Strazicizh, M. C. (2003). Minimum lagrange multiplier unit root test with two structural breaks. The Review of Economics and Statistics, 85(4), 1082-1089.

Lee, J. ve Strazicich, M. C. (2004). Minimum LM Unit root test with one structural break. Appalachian State University Working Papers, 04(17), 1-15.

Mankiw, N. G., Romer, D. ve Weil, D. N. (1992). A contribution to the empirics of economic growth. The Quarterly Journal of Economics, 107, 407-437.

Meng, M., Payne J. E. ve Lee J. (2013). Convergence in per capita energy use among OECD countries. Energy Economics, 36, 536-545.

Meng, M., Im K. S., Lee J. ve Tieslau MA. (2014). More powerful LM unit root tests with non-normal errors. Editörler: Sickles RC, Horrace WC. İçinde: Festschrift in honor of peterschmidt. New York: Springer, s.343-357.

Önder, A.O:, Deliktas, E. ve Karadağ, M. (2010). The impact of public capital stock on regional convergence in Turkey. European Planning Studies, 18(7), 1041-1055.

Rassekh F. (1998). The Convergence hypothesis: History, theory and evidence. Open Economies Review, 9, 85-105.

Sağbas, I. (2002). Türkiye'de kamu harcamalarının yakınsama üzerindeki etkisi. Afyon Kocatepe Universitesi İktisadi ve İdari Bilimler Fakültesi Dergisi, 4, 137-148.

Sala-i-Martin, X. (1995). The clasical approach to convergence analysis. Economic Working paper, 117, 1-28.

Sen, A. (2003). On unit-root tests when the alternative is a trend-break stationary process. Journal of Business \& Economic Statistics, 21(1), 174-184.

Sevüktekin, M. ve Çınar, M. (2017). Ekonometrik zaman serileri analizi E views uygulamalı. Geliştirilmiş 5. Baskı, Bursa: Dora Yayıncılık.

Solow, R. M. (1956). A contribution to the theory of economic growth. The Quarterly Journal of Economics, 70, 65-94.

Soyyiğit, S. (2018). Türkiye'nin kriz öncesi ve kriz sonrası dönemde il bazında yakınsama analizi. Social Sciences Studies Journal, 4(16), 1279- 1287.

Tansel, A. ve Güngör, N.D. (1999). Economic growth and convergence: An application to the provinces of Turkey, s.1975-1995. METU-ERC Working Paper.

Temel, T., Tansel, A. ve Güngör, N.D. (2005). Convergence of sectoral productivity in Turkish provinces: Markov Chains model. International Journal of Applied Econometrics and Quantitative Studies, 2(2), 1-35. 
Yamak, R. ve Yamak, N. (1999). Türkiye'de gelir dağılımı ve iç göç. DEÜ Sosyal Bilimler Enstitüsü Dergisi, 1(1), 16-28.

Yamanoğlu, K.K. (2008) Türkiye'de sosyo-ekonomik faktörlerin iller arası yakınsama üzerine etkileri. İstatistikçiler Dergisi: İstatistik ve Aktüerya, 1(1), 3349.

Yildırım, J. (2005). Regional policy and economic convergence in Turkey: A spatial data analysis. 18th European Advanced Studies Institute in Regional Science, s.1-10.

Yılmaz, M. ve Kesbiç, C. Y. (2020). Kırılgan beşli ekonomileri için yakınsama hipotezinin geçerliliği. Elektronik Sosyal Bilimler Dergisi, 19(75), 12751293.

Zeren, F. ve Yılanc, V. (2011). Türkiye'de bölgeler arası gelir yakınsaması: Rassal katsayılı panel veri analizi uygulaması. Business and Economics Research Journal, 2, 144-152.

\section{Kaynakça Bilgisi/Citation Information}

Demirel, E. ve Kurt, Ü. (2021). Türkiye ekonomisinde yakınsama hipotezi geçerliliğinin test edilmesi: G7 grubu ülke örneği. OPUSUluslararası Toplum Araştırmaları Dergisi, 18(44), 7777-7794. DOI:10.26466//opus.908963. 